використання як комплексного навчального предмета, освітнього та виховного значення, термінологічної бази. Подальшого вивчення потребує аналіз форм і методів навчальної та позанавчальної краєзнавчої роботи загальноосвітніх закладів України у XIX - на початку XX ст.

\title{
Література
}

1. Ващенко Г. Виховання волі і характеру / Г. Ващенко. - Боффало-Мюнхен. 1957. - 273 с. 2. Ващенко Г. Виховний ідеал / Г. Ващенко. - Полтава: Полтавський вісник, 1994. - 191 с. 3. Русова С. Дидактика / С. Русова // Вибрані педагогічні твори. - К. : Либідь, 1997. - Кн. 2. - С. 134-300. 4. Русова С. Теорія і практика дошкільного виховання / С. Русова // Вибрані педагогічні твори. - Кн. 1. - К. : Либідь, 1997. - С. 171-258. 5. Русова С. Шкільні екскурсії і їх значення / С. Русова // Вибрані педагогічні твори. - Кн. 1. - К. : Либідь, 1997. - С. 117-125. 6. Сковорода Г. Вірші. Пісні. Байки. Діалоги. Трактати. Притчі. Прозові переклади. Листи. / Г. Сковорода. К. : Наукова думка, - 1983. - 543 с. 7. Ушинский К. Д. Воспоминания об обучении в Новгород-Северской гимназии / К. Д. Ушинский// Педагогические сочинения : в 6 т. - М. : Педагогика, 1988. - Т. 1. - С. 309-316. 8. Ушинський К. Д. Педагогічна подорож до Швейцарії / К. Д. Ушинський // Вибрані педагогічні твори : в 2-х т. - К. : Радянська школа, 1983. - Т.2. Проблеми російської школи. - С.64-169. 9. Ушинський К. Д. Про народність у громадському вихованні / К. Д. Ушинський // Вибрані педагогічні твори : в 2-х т. - К. : Радянська школа, 1983. - Т. 1. Теоретичні проблеми педагогіки. - С. 43-103. 10. Франко І. Я. Твори у 50-ти томах / I. Я. Франко - К. : Наукова думка, 1985. - Т. 46. - Кн. 2. - 439 с. 11. Хрестоматія 3 iсторії педагогіки. Частина I. Вітчизняна школа і педагогіка/ [наук. редактор А. А. Сбруєва]. - Суми : СДПУ ім. А. Макаренка, 2003. - 299 с.

УДК: 371.134:63(4)

Вікторія Власова

\section{ФОРМУВАННЯ ЄВРОПЕЙСЬКОГО ВИМІРУ ФРАНЦУЗЬКОЇ УНІВЕРСИТЕТСЬКОЇ ЕКОЛОГІЧНОЇ ОСВІТИ}

Власова В. П. Формування європейського виміру французької університетської екологічної освіти.

У статті досліджено проблему формування європейського виміру у вищій екологічній освіті Франції. Досліджено питання інтернаціоналізації вищої екологічної освіти. Здійснено аналіз документів. Зазначено основні тенденцій розвитку університетської екологічної освіти Франції. Встановлено, що французька система вищої освіти на сьогодні характеризується максимальною інтеграцією навчального процесу, професіоналізацією університетського сектору та професійно-орієнтованими напрямками підготовки фахівців екологів. Проаналізовано нові перспективи для європейського виміру вищої екологічної освіти до 2020 року.

Ключові слова: загальноєвропейська система вищої освіти, етап інтернаціоналізації, європейський вимір вищої екологічної освіти Франції, інтернаціоналізація вищої екологічної освіти.

Власова В. П. Формирование европейского измерения французского университетского экологического образования.

Статья посвящена исследованию вопроса формирования европейского измерения в высшем экологическом образовании Франции. Исследованы вопросы 
интернационализации высшего экологического образования. Осуществлен анализ нормативных документов. Указаны основные тенденции развития университетского экологического образования Франции. Установлено, что французская система высшего образования на сегодняшний день характеризуется максимальной интеграцией учебного процесса, профессионализацией университетского сектора и профессионально-ориентированными направлениями подготовки специалистов экологов. Проанализированы новые перспективы для европейского измерения высшего экологического образования до 2020 года.

Ключевые слова: общеевропейская система высшего образования, этап интернационализации, европейское измерение высшего экологического образования Франции, интернационализация высшего экологического образования.

Vlasova V.P. Creating a European dimension French university environmental education.

The article investigates the issue of forming a European dimension in higher environmental education in France. The issue of internationalization of higher environmental education. The analysis of regulations and determined that the current higher environmental education France determined by the principles of many of them. Outlines the environmental trends of university education in France. It was established that the French higher education system today has a maximum integration of the educational process, the professionalization of the university sector and professionally-oriented areas of training environmental experts. Analyzed new perspectives for the European dimension of higher environmental education by 2020.

Key words: European system of higher education internationalization stage, the European dimension of higher environmental education France, internationalization of higher environmental education.

Важливим для нашого дослідження $є$ те, що задля полегшення визнання професійних компетентностей та інтернаціоналізацією освітнього простору відбувається створення на університетському, національному й загальноєвропейському рівнях взаємовизнаних систем забезпечення якості освіти, які формують європейський вимір університетської освіти. Підвищення якості освіти в університетах Європи розглядається як комплексна проблема, що вимагає підвищення ефективності викладацької, дослідницької та управлінської діяльності, під час розв'язання якої необхідно дотримуватися балансу між нововведеннями і традиціями, академічними перевагами й соціально економічною необхідністю, зв'язністю програм і свободою вибору студентів. Питання ефективності європейської університетської освіти належать до пріоритетних. Тому, досліджуючи питання європейських інтеграційних процесів вищої екологічної освіти у Франції, важливим є визначення терміну «європейський вимір в освіті» та дослідження в галузі формування європейського виміру французької університетської екологічної освіти.

Із 2001 року за підтримки Міністерства досліджень організуються постійні щорічні колоквіуми з питань вищої освіти. Водночас у Франції починають набули поширення дослідження, що стосуються університетської екологічної освіти (G. Chartier, G. Attali, J.-C. Hardouin, A. Hussenet, G. Septours, N. Bottani, F. Pallez, M.-H. Prieur, J.-P. Nougier, N. Klotz, C. Thelon, J.-J. Pau, C. G. Cortines).

Французьких науковців передовсім цікавить розв'язання таких проблем:

- Реформування вищої освіти. Пошуковець V. Reding аналізує реформи вищої 
освіти європейських країн i констатує, демонстрування загальних тенденцій, характерних для всіх країн Свропи.

- Розвиток міжнародної мобільності. У низці досліджень розглядаються основні напрямки розвитку міжнародної мобільності, цільові пріоритети, а також умови активної організації у практиці університетської освіти Франції. Розвиток мобільності позиціонується як необхідність сучасного університету відповідати потребам суспільства.

- Оцінка якості системи національної освіти загалом (C. Thelon) i конкретних університетів зокрема (Ph. Lhermer, A. Michel).

- Визначення нових цілей і завдань університетів в умовах створення єдиного європейського виміру вищої освіти (С. Cortines, F. Pallez, J.-P. Nougier, N. Klotz), створення нових дипломів (J.-J. Paul) i освітніх моделей, розвиток міжнародної діяльності університетів.

Відтак французькими авторами вивчаються питання щодо модернізації адміністративного управління університетами (B. Dizambourg), особливостями освітньої системи дистанційної і приватної форми навчання (G. Chartier), а також тенденції розвитку вищої екологічної освіти (J.-С. Hardouin, A. Hussenet, G. Septours, N. Bottani).

Метою статmі є визначення поняття «європейського виміру освіти» та визначення основних чинників формування європейського виміру французької університетської екологічної освіти.

Французька модель освіти визначає за пріоритет значущість надбання учнівської молоддю екологічних знань, особливо, наукових екологічних понять, необхідних для розуміння біофізичних, економічних i соціальних механізмів функціонування довкілля.

Важливим поняттям для дослідження питання розвитку єдиного європейського освітнього простору вищої освіти є «європейський вимір освіти».

Метою створення європейського простору вищої освіти визначено «якість основа для довіри, релевантності, мобільності, сумісності та привабливості» [9].

Базовим у дослідженні європейських інтеграційних процесів вищої освіти у Франції є поняття «європейський вимір в освіті» (dimension europeenne), означає нову тенденцію розвитку освіти європейських країн і (Резолюції Ради європейських міністрів освіти про програму дій в освіті (19 лютого 1976 року).

Європейський вимір освіти - це культурологічний погляд, який дозволяє виявити глибинні напрямки розвитку сучасної освіти в Свропі 3 урахуванням розвитку культури кожної країни [1].

У Франції екологічна освіта набула інтенсивного розвитку після прийняття Міністерством освіти серії документів, що заклали фундамент цієї надзвичайно важливої галузі соціально-педагогічної практики.

Початком формування європейського виміру французької університетської екологічної освіти задекларовано 1972 рік, коли на конференції в Стокгольмі на міжнародному рівні офіційно визнано, що вища освіта відіграє важливу роль в стимулюванні збереження довкілля. 3 того часу розроблено достатню кількість академічних декларацій, статутів і угод, метою яких є сприяння розвитку освіти в галузі навколишнього середовища, освіті в рамках сталого розвитку. Розпочинаючи 1987 року спостерігається зростання подібних проектів. У табл. 1 показано, що значну частину декларацій про вищу екологічну освіту розроблено у Свропі. 


\section{Хронологія ініціатив упровадження принципів сталого розвитку}

у галузь вищої екологічної освіти Франції

\begin{tabular}{|c|c|c|}
\hline № & ік & 17 Деклар \\
\hline 1. & 972 & $\begin{array}{l}\text { тишнього середовища, конференція ООН } \\
\text { ища, Швеція }\end{array}$ \\
\hline 2. & 1975 & $\begin{array}{l}\text { Белградська хартія, Белградська конференція по екологічній освіті, } \\
\text { Югославія }\end{array}$ \\
\hline 3. & 1977 & $\begin{array}{lllllll}\text { Тбіліська декларація, Міжурядова } & \text { конференція } & 3 & \text { освіти } & \text { в } & \text { галузі } \\
\text { навколишнього середовища, Грузія }\end{array}$ \\
\hline 4. & 1991 & $\begin{array}{l}\text { Галіфакська декларація, університетська конференція } 3 \text { питань сталого } \\
\text { розвитку і охорони навколишнього середовища, Канада }\end{array}$ \\
\hline 5. & 992 & $\begin{array}{l}\text { Доповідь конференції ООН } 3 \text { навколишнього середовища і розвитку } \\
\text { (Конференція в Ріо-де-Жанейро); повістка дня ХХІ століття, розділ 36: } \\
\text { розвиток освіти і громадської обізнаності; розділ 35: наука в умовах сталого } \\
\text { розвитку. }\end{array}$ \\
\hline 6. & 1992 & \begin{tabular}{|lrlllll} 
Асоціація Лідерів & університетів & 3 & питань & стійкого & розвитку & для \\
майбутнього, США
\end{tabular} \\
\hline 7. & 1993 & $\begin{array}{l}\text { Кіотська Декларація, Міжнародна асоціація університетів, дев’ятий } \\
\text { круглий стіл, Японія }\end{array}$ \\
\hline 8. & 993 & ції університетів співдружності \\
\hline 9. & 1993 & енція ректорів С \\
\hline 10. & 996 & $\begin{array}{l}\text { оситет Болл, Екологізація університетської спільноти, } \\
\text { 1999, 2001, 2003, 2005, 2007, i } 2009 \text { pp. }\end{array}$ \\
\hline 11. & 1997 & $\begin{array}{l}\text { Салонікська декларація, Міжнародна конференція «Навколишнє } \\
\text { середовище та суспільство: освіта і поінформованість громадськості про } \\
\text { принципи стійкого розвитку», Греція }\end{array}$ \\
\hline 12. & 999 & $\begin{array}{l}\text { Конференція «Управління навколишнім середовищем для збереження } \\
\text { стійкості університетів», вперше проходила в Швеції. Наступні: в } 2002 \\
\text { (Южно-Африканська Республіка), } 2004 \text { (Мексика), } 2006 \text { (США), } 2008 \\
\text { (Іспанія), і } 2010 \text { (Голландія) }\end{array}$ \\
\hline 13. & 001 & $\begin{array}{l}\text { Люнебургська декларація про вищу освіту в інтересах сталого розвитку, } \\
\text { Німеччина }\end{array}$ \\
\hline 14. & 2002 & $\begin{array}{l}\text { Всесвітній саміт зі сталого розвитку в Йоганнесбурзі, Південно- } \\
\text { Африканська Республіка (результат - Декада програми освіти в інтересах } \\
\text { сталого розвитку; громадський результат громадянського суспільства: } \\
\text { Декларація Убунту) }\end{array}$ \\
\hline & & \\
\hline
\end{tabular}

Особливістю останніх років є цілеспрямована спільна діяльність європейських країн у формуванні загальноєвропейської системи освіти в рамках Болонського процесу та створенню $з 2010$ року «європейського простору вищої освіти», де «національні особливості й загальні інтереси можуть взаємодіяти і підсилювати один одного для вигоди Європи, ії учнів та в більш загальному сенсі - громадян» [8]. 
Важливим підгрунтям для майбутнього створення європейського виміру освіти стала реформа Ліонеля Жоспена, проведена у 1988-1992 роках. На його думку, освіта Франції має відповідати європейським вимогам, освітній політиці Європейської Співдружності, перспективі створення єдиного ринку; сприяти розвитку обміну між студентами й викладачами. Л. Жоспен уважав, що необхідно «зблизити деякі університети з Вищими школами і державними лабораторіями, щоб створити науково-освітні конгломерати європейського значення» [5].

Нині, розглядаючи питання формування європейського виміру університетської екологічної освіти Франції, треба зазначити, що сучасна вища освіта Франції визначається принципами багатьох нормативних документів.

Так, у Сорбонській декларації (травень 1998), Болонській спільній декларації європейських міністрів освіти 29 країн (червень 1999 року), заяві- Формування Майбутнього, прийнятій на конференції за участю більше 300 європейських вищих навчальних закладів (Саламанка, березень 2001 року), в Празькому Комюніке європейських міністрів, відповідальних за вищу освіту (травень 2001 року) сформульовані загальні цілі, завдання, основні принципи, ключові напрямки розвитку національних вищих шкіл і формування європейського виміру вищої освіти [3]. У рекомендаціях Комітету Конвенції про визнання кваліфікацій із вищої освіти у європейському регіоні відзначається, що вони мають «безпосереднє відношення до процесу посилення інтернаціоналізації вищої освіти» [7].

У травні 1998 р. підписано Сорбонську декларацію, спрямовану на:

- створення відкритого Європейського простору вищої освіти, яка повинна стати більш конкурентоспроможною на ринку світових освітніх послуг завдяки зрозумілості дипломів, кваліфікацій і ступенів; магістр);

- орієнтацію переважно на двоступеневу структуру вищої освіти (бакалавр-

- використання системи кредитів (ECTS);

- міжнародне визнання бакалавра i надання йому права вибору форми подальшого навчання, зокрема, в магістратурі чи докторантурі;

-стимулюванню процесу вироблення єдиних рекомендацій для зближення систем освіти та формування європейського простору вищої освіти [2].

У червні 1999 року в Болоньї міністрами освіти 29 європейських країн була підписана «Декларація про Свропейський вимір для вищої освіти». Довгострокова мета цієї програми - «підвищення мобільності громадян на ринку праці та посилення конкурентоспроможності європейської вищої освіти». Вищу освіту в Європі пропонується перевести на трирівневу основу: бакалавр - магістр - доктор (PhD) [4].

Цікавим $є$ те, що Франція (як і багато інших країн учасників Болонського процесу) не ставить перед собою завдання створення єдиних європейських освітніх програм. Навпаки, підтримується варіативність вищої освіти 3 пошуком шляхів його індивідуалізації.

Відтак реалізація ключових позицій Болонської декларації у вищій екологічній освіті Франції передбачає: багаторівневість освіти, запровадження кредитної системи, підвищення якості освіти, розширення мобільності студентів і викладачів, забезпечення працевлаштування випускників.

Важливим для формування європейського виміру французької університетської екологічної освіти $є$ визначення пріоритетних напрямків інтернаціоналізації. Так, у документі Міністерства вищої освіти Франції (1995 рік) пріоритетні напрямки визначено так: 
- обмін студентами 3 індустріально розвиненими країнами (особливо - 3 країнами Свросоюзу);

- гарантії взаємного визнання дипломів про вищу освіту;

- створення інтернаціональних навчальних програм;

- погодження національних програм вищої школи третього циклу із програмами післяуніверситетської освіти у країнах, які дотримуються англо-американської моделі «бакалавр-магістр-доктор».

Головними чинниками, які безпосередньо формують європейський вимір французької екологічної вищої освіти, є:

1) реформа L-M-D;

2) система кредитів ECTS;

3) центр визнання кваліфікацій (дипломів): NARIC;

4) визнання кваліфікацій (дипломів) в Свропейському Союзі.

Аналізуючи інформаційний центр 3 академічного i професійного визнання професійних кваліфікацій (ENIC-NARIC) як чинник впливу на формування європейського виміру у французькій вищій освіті, зауважимо, що центр охоплює дві мережі:

- NARIC (утворено у 1984 році за ініціативи Європейського союзу) несе відповідальність за: створення сертифікатів дослідження навчання міжнародного рівня, задля надання інформації про системи освіти і процес професійної підготовки, у рамках реалізації Болонського процесу, метою якого є покращення мобільності в Европі;

- ENIC (утворено в 1997 році за ініціативи ЮНЕСКО і Ради Свропи) забезпечує (в країнах Свропи) мережі контактних пунктів, які здатні забезпечити законодавчою інформацію, що стосується вищої професійної освіти (визнання дипломів, забезпечення якості, LMD, ECTS, додаток до диплома), статистика і система національних кваліфікацій.

Досліджуючи питання визнання кваліфікацій (дипломів) в Європейському Союзі, зазначимо, що у Франції наявні два види визнання дипломів: професійний (сертифікація) і академічний [6].

Після двох директив, прийнятих у 1989 і 1992 роках встановленні (89/48 та 92/51), які затверджують загальну систему визнання кваліфікацій, директивою 2005/36 від 7 травня 2005 року узагальнено й оновлено правову основу для визнання професійних кваліфікацій професійної практики, регламентованої в СС. Ці положення дозволяють усім компетентним особам отримати визнання їх професійної кваліфікації, яку вони отримали у своїй країні, у цілях здійснення професійної діяльності в іншій державі.

Проаналізуємо нові перспективи для європейського виміру вищої екологічної освіти до 2020 року.

28 і 29 квітня 2009 року в Льовені міністри вищої освіти держав-членів Болонського процесу (46 держав) вирішили консолідувати вже вжиті задля утворення європейського сектору реформи вищої освіти, а саме:

- реалізація і розширення європейських стандартів в аспекті якості;

- прогресивна система Європейського реєстру рейтингових агентств;

- упровадження навчання та дипломів про вищу освіту розглядається 3 позиції надбання знань, навичок і умінь;

- прийнятне професійне працевлаштування за допомогою навчання протягом усього життя; 
- розвиток і демократизація мобільності у Європі;

- підсилення керівництва, надання додаткової інформації та дія навчальної ради для повного успіху студентів.

Основними перспективами до 2020 року можна вважати такі:

- враховування соціального аспекту, який корелює з вищою освітою і навчанням протягом усього життя;

- сприяння навчанню 3 акцентом на здобутті навичок i здібностей працевлаштування студентів після закінчення навчання;

- розширення міжнародної відкритості установ і розвиток мобільності, яка «має стати візитною карткою європейського простору вищої освіти». Отже, до 2020 року, «принаймні, щоб 20\% випускників навчались за кордоном»;

- стежити за розвитком інструментів, які надають більш детальну і відкриту інформацію про вищі навчальні заклади.

11 і 12 березня 2010 року відбулася конференція 3 нагоди дня народження Болонського процесу, організована Австрією та Угорщиною (Відень і Будапешт).

Підтверджуючи цілі Льовенської зустрічі, спрямовані на розвиток мобільності, на принцип особистісно зорієнтованої освіти та на підготовку кадрів соціального виміру, 47 міністрів підкреслили необхідність:

- поглиблення реформ якомога ближче до кожного вищого навчального закладу;

- враховування навантеження студентів і викладачів;

- обговорення цілей та результатів навчального процесу;

- визначенння відповідальності уряду щодо вищої екологічної освіти.

Ураховуючи цілі, поставлені на зустрічі у Льовені, Свропейські міністри зустрілися на Конференції в Бухаресті (Румунія) 27 і 28 квітня 2012 року, щоб гарантувати на найвищому можливому рівні вищій освіті державне фінансування.

Наступним кроком у формуванні вищої екологічної освіти Франції стане конференція Єреван (Вірменія) в 2015 році, узагальнять підсумки нових досягнень, зроблених в період з 2012-2015 роки.

Здійснений теоретичний аналіз формування європейського виміру французької університетської екологічної освіти надав підстави стверджувати, що інтернаціоналізація вищої екологічної освіти створює нові можливості, сприяє підвищенню доступності освіти та їі якості, упровадженню інноваційних методів роботи в системах вищої освіти, зміцненню міжнародного співробітництва в цій галузі.

Отже, європейський вимір французької університетської екологічної освіти формується завдяки високій конкурентоспроможності, максимальній інтеграції навчального процесу, професіоналізації університетського сектора, професійноорієнтованим напрямкам підготовки фахівців-екологів, а також високою якістю освіти й системою контролю за якістю освіти.

\section{Література}

1. Вища освіта України і Болонський процес: [навч. посіб.] / М. Ф. Степко, Я. Я. Болюбаш, В. Д. Шинкарук та ін.; за ред. В. Г. Кремня. - Тернопіль : навч. книга - Богдан, 2004. - 384 с. 2. Колот А. Реалізація основних принципів Болонської декларації при підготовці фахівців економічного профілю / А. Колот // Вища школа. 2004. - № 2-3. - С. 20-33. 3. Сорбонская декларация по гармонизации европейской системы высшего образования [Электронный ресурс]. - Париж, Сорбона. 25 мая 1998. - Режим доступа: http://www.france-jus.ru/upload/docs/Declaration_Sorbonne.pdf. 4. Bologna Declaration. Joint Declaration of the European Ministers of Education Convened in Bologna on the 19th of June 1999. 5. Conférence mondiale sur l'enseignement supérieur 
L'enseignement supérieur au XXIe siècle. [Електронний ресурс]. - Режим доступу: http://unesdoc.unesco.org/images/ 0011/001163/116345f.pdf 6. Nouveaux espaces pour l'Université. Rapport au Président de la République. - Paris : CNE, 2005. - 129 p. 7. The Bologna Declaration on the European space for higher education: an explanation.19.06.1999 [Електронний ресурс]. Режим доступу: http://www.ec.europa.eu/education/policies/educ/bologna/bologna.pdf. 8. The European Higher Education Area. Joint Declaration of the European Ministers of Education. Convened in Bologna on the 19th of June 1999 [Електронний ресурс]. - Режим доступу: http://www.ntb.ch/ SEFI/bolognadec.html. 10. Towards the European Higher Education Area. Communique of the meeting of the meeting of European Ministers in charge of Higher Education in Prague on May 19th 2001 [Електронний ресурс]. - Режим доступу : http://www.msmt.cz/Summit/Prague\% 20Communique\%20-\%2019-05-2001FINAL.doc.

УДК : 378:378.4-057.875(043.3)

Діана Волківська

\section{НАУКОВІ ПІДХОДИ ДО РОЗУМІННЯ ПОТЕНЦАЛУ ОСОБИСТОСТІ}

Волківська Д. А. Наукові підходи до розуміння потенціалу особистості.

У статті розкрито сутність поняття «потенціал особистості» та представлено результати теоретичного аналізу дослідження потенціалу особистості науковцями різних галузей.

Ключові слова: особистість, потенціал, можливості, ресурси, засоби.

Волковская Д. А. Научные подходы к пониманию потенциала личности.

В статье раскрыта сущность понятия «потенциал личности» и представлены результаты теоретического анализа исследования потенциала личности ученими разных отраслей.

Ключевые слова: личность, потенциал, возможности, ресурсы, средства.

Volkivska D. A. Scientific approaches to understanding the potential of the individual.

The article deals with the essence of the concept of «individual capacity» and presents the results of theoretical analysis research potential of the individual scientists from different fields.

Key words: personality, potential, opportunities, resources, tools.

В умовах сучасних соціально-економічних перетворень важливо адекватно реагувати на зміни, для цього потрібно активізувати особистісний потенціал. Кожна людина, без сумнівів, унікальна. Водночас для більшості людей є проблемою достойно презентувати себе світові, довести свою унікальність, розкрити приховані можливості та ресурси.

Тому пошук шляхів розвитку потенціалу особисті $\epsilon$ важливим завдання сьогодення.

Потенціал особистості був предметом вивчення античної філософії (Аристотель, Геродот, Платон, Плутарх) i не втратив актуальності для сучасної науки (Т. Артемьєва, В. Бережна, Д. Берлайн, А. Голованова, Н. Дериглазова, А. Деркач, В. Марков, Н. Миронець, Л. Сохань, І. Утюж). Та проведений теоретичний аналіз надає нам підстави говорити про неоднозначність тлумачення потенціалу особистості дослідниками різних галузей. 